\title{
Question of Values
}

\author{
Horacio González Rodríguez* \\ College of Professionals in Psychology of Costa Rica, Costa Rica
}

\section{Opinion}

When we talk about values, we immediately think this refers to ethics, but we could start with its basic definitions. As for example the so-called universals are the principles; thus justice, honor, honesty, peace among many others are usually respected by the common people as universal principles, correct and appropriate for social coexistence, and not necessarily all those that respect a scale of values, They respect the principles, because in gangsters they have scales of values to coexist as groups but with the difference that they disrespect all principles.

On the other hand, when I try to return the principle as mine or my property, then I am converting the principle into value, and I put it into practice and preservation in my daily life, then we could say that from constant and repetitive practice I begin to acquire good habits that I turn into virtues, like the practice of bad habits promoted by anti values or the opposite of the values established and defended in the universal principles within a society; then we can say that we develop the vices that would be the opposite of the virtues.

Ethics, unlike what many think, occurs and is defined when choosing, then we ourselves make the choice to defend that act that represents that value in which we believe so much, or on the contrary we decide to break it, and we talk much about the ethics of minimums and maximums, the reason for the higher good or higher premium on which values we must defend and prioritize above others and for the common good, being above the lesser good.

At the social level it is often confused with quite regularity, ethics that of personal values with morals, that of universal principles that build daily social coexistence and without which many of these things that make us civilized humans would definitely not exist.

Many times the rule and the exception, and their difference, are not understood either, so we see political and religious entities, arguing about abortion for example and it is not about being in favor or against, but we must accept that there must be a Exception where for social or humanitarian reasons an abortion should be done, perhaps in the case of a very young girl who should not go through the experience of conceiving, not being at the appropriate time for motherhood, not having had free will to say "Well, I got into this and I have to bear the responsibility for the action I have committed" but unfortunately it is not like that as it is a controversial issue, they prefer not to discuss it, and say that it is better for the girl to suffer and perhaps the infant or both expose themselves to the danger of death, it is as if due to a lack of ethical training and common sense. Because although the principle together with the value leads us to the ethical rule of defending life and not approving abortion, we have to take into account the relevant exception so that the rule exists and can be practiced correctly.

Thus many times the deontological code, or many times misnamed code of ethics, is misinterpreted because the set of rules, or built on the basis of policies, dictate the correct path to work within a union, a public institution and even a company private who respects herself. And the members, by accepting membership in said instance, undertake to respect the code or, where appropriate, the policy that represents coexistence in values under certain actions.

It is said that among the best ways to learn values, one is found in aesthetics, because Aristotle said ethics enters through aesthetics, the so-called structuralist movements affirm that contemplat-

\begin{tabular}{|l|l|}
\hline \hline Quick Response Code: & *Corresponding author: Horacio González Rodríguez, College of Professionals in Psychology \\
of Costa Rica, Costa Rica & \\
Received: 04 January, 2022 & Published: 17 January, 2022 \\
& Citation: Rodríguez HG. Question of Values. J Psych Sci Res. 2022;2(1):1-2. DOI: \\
\hline
\end{tabular}


ing art whether it is a painting, a sculpture, or also the art itself found within literature, can lead us to points of reflection so deep that it allows us to promote self-knowledge, and from there also develop our corresponding ethics and values.

In entrepreneurship and business development books, we are told that certain entrepreneurial and business skills inevitably connect us with the respective values that we want to acquire, so teamwork could connect us with solidarity, leadership with responsibility, assertive communication and empathy with respect for among other more possible examples, since it is said that building large companies is like developing better social coexistence, since only the excellence of the leaders and those close to them, along with the rest of the staff in charge can build things like companies that give their contribution to a better world and a service to the society they inhabit and transcend borders with their service.

Ethics and values can never be imposed, since free will is needed so that the appropriate ethical exercise can be raised, except in their respective exceptions, so laws cannot be passed in legislative or executive contexts and saying this is going to be called the new ethics of the country, because we forget that ethics is also modeled with ourselves from a young age, with the example that parents give their children, because the true school of ethics and values and where the principles are respected is called the family, and if a parent tells his son something that is an important value and he practices the opposite, what more could we add. Just follow the example of the parents.

\section{Acknowledgements}

None.

\section{Funding}

None.

\section{Conflict of Interest}

No conflict of interest. 